\title{
Strategi Bertutur Dalam Tuturan Memerintah Pada Situasi Komedi Tukang Ojek Pengkolan (Eps. 9)
}

\author{
Prapti Wigati Purwaningrum \\ ABA BSI \\ Jl. Salemba Tengah no. 45 Jakarta pusat \\ Prapti.pwp@bsi.ac.id
}

\begin{abstract}
There many kind of speech acts shows in this sitcom, but the writer just want to focus on commands. It includes into directive speech act, means the utterances which give the effect to the hearer to do something. In this analysis the writer wants to know how the characters in this sitcom utters the commands in polite way. It is because the speaker must save the hearer's face. So, this tendency draws interest to find politeness strategy in command. This paper is using dialog script of tukang ojek pengkolan (TOP). In this analysis the writer uses speech act theory by Searl, pragmatic theory by Austin, and politeness strategy by Brown C. Levinson. Based on the analysis the writer found some commands which uttered by politeness strategy off record and bald record. Some charecters in this serial comedy series Tukang Ojek Pengkolan preferred off record to bald record in their commands. By using this strategy, the characters uttered indirectly or vaguely to the hearer. In this strategy, the speaker tried to avoid the direct FTA, and it removes the characters from the potensial of being imposing.
\end{abstract}

Keywords: Pragmatic, speech act, politeness strategy, Tukang Ojek Pengkolan (TOP) cpt.9

\section{PENDAHULUAN}

Saat ini situasi komedi menjadi tayangan televisi yang cukup diperhitungkan dalam merebut perhatian pemirsanya. Masyarakat yang sudah cukup jenuh dengan berbagai berita politik yang cukup menguras pikiran, sinetron yang tidak sedikit menyita emosi penonton, maka dengan munculnya situasi komedi menjadi tontonan yang cukup menyegarkan. Alur cerita yang ringan, kepolosan dari masing masing karakter sehingga membawa cerita mudah dipahami. Tukang ojek pengkolan menjadi salah satu sitkom yang cukup memikat hati pemirsa saat ini.

Tukang ojek pengkolan yang tayang di RCTI setiap sore dengan durasi 1,5 jam, memberikan angin segar bagi pemirsa. Sitkom ini mengisahkan tentang kehidupan tukang ojek dengan segala suka dukanya. Bagaimana mereka bersaing dalam memperoleh penumpang, bagaimana kisah cinta mereka, dan tidak lupa bagaimana mereka menyikapi segala kejadian yang ada disekitar mereka.

Dalam mengisahkan setiap alur ceritanya tidak lepas dari tuturan yang dituturkan oleh setiap pemain. Ada tuturan yang maksud tuturannya dituturkan secara langsung, tetapi tidak jarang juga pada beberapa tuturan yang banyak mengisyaratkan maksud lain dan responpun terkadang diberikan oleh petutur yang sepintas tidak menjawab tuturan sebelumnya. Tidak jarang pula tuturan seperti ini memaksa pemirsa sitkom tersebut untuk menggali makna sebelum dapat memahami apa yang dimaksudkan dalam tuturan tersebut. Hal inilah yang terkadang memancing tawa bagi pemirsa, karena terdengar seolah percakapan mereka tidak nyambung satu sama lain. Meskipun demikian alur cerita tetap menarik dan permirsa dapat dengan mudah memahaminya. Justru dengan berbagai tuturan yang seperti itu semakin menambah keunikan sitkom tersebut.

Grice berpendapat jika ingin sebuah komunikasi berhasil maka masing-masing penutur dan petutur harus patuh pada prinsip kerja sama (PKS) termasuk dengan keempat bidalnya. Namun jika melihat beberapa penggalan tuturan dalam dialog antar pemain di Tukang ojek Pengkolan banyak sekali yang seolah tidak nyambung, dengan demikian pelanggaran maksim terjadi. Hal ini mengakibatkan seolah masing-masing ujaran tidak nyambung namun masing-masing pemain memahami, situasi ini memunculkan adanya implikatur dalam beberapa ujaran dalam sitkom ini. Implikatur ini juga muncul saat para tokoh dalam sitkom tersebut menuturkan tuturan memerintah.

Tuturan memerintah merupakan tuturan yang memiliki maksud memerintah atau menyuruh orang melakukan sesuatu. Dalam sitkom ini para tokoh ada yang menuturkan tuturan memerintah secara langsung dan tidak langsung, Pada saat penutur menuturkan tuturan memerintah ada yang mengemasnya melalui sebuah pertanyaan, menyerupai sindiran. Dalam menjaga muka, penutur dan petutur dalam sitkom Tukang Ojek Pengkolan (TOP) juga menggunakan strategi bertutur. Semua itu memiliki pertimbangan yaitu dengan adanya keinginan penutur menjaga keterancaman muka dari penutur dan petutur. dengan demikian masing masing dari penutur dan petutur sama-sama dapat saling menghargai dan dapat meminimalkan konflik 
serta kesalahpahaman yang mungkin timbul pada saat tuturan dituturkan.

Dalam tulisan ini penulis ingin mengetahui bagaimana tuturan memerintah yang dituturkan oleh para pemain sitkom Tukang Ojek Pengkolan (TOP) dan strategi bertutur apa yang paling sering digunakan berkaitan dengan hubungan kedekatan mereka. Penulis hanya mengumpulkan data dalam satu episode penayangan dengan durasi 1,5 jam.

\section{METODOLOGI PENELITIAN}

\section{Materi}

Data percakapan dalam sitkom Tukang Ojek Pengkolan eps. 9 dipilih sebagai objek kajian. Dialog tersebut ditulis oleh Sokat Rachman. Alur cerita tersebut sangat mudah dipahami dan ringan untuk dinikmati, selain itu dalam percakapan tersebut banyak ditemukan berbagai implikatur. Oleh karena itu penulis memilih percakapan dalam sitkom tersebut sebagai sumber data.

\section{Prosedur}

Dari naskah percakapan yang ada dalam sitkom tersebut, penulis mengelompokan terlebih dahulu tuturan-turan yang memiliki maksud memerintah. Setelah data terkumpul semua lalu dilihat bagaimana penutur menuturkannya, Dalam hal ini dilihat berdasarkan strategi bertutur dari Brown Levinson.

Tinjauan Pustaka

Pragmatik

Menurut Gazdar dalam Nadar, Pragmatik adalah kajian antara lain mengenai deiksis, implikatur, presuposisi, tindak tutur, dan aspek-aspek struktur wacana.

\section{Aspek Tutur}

Menurut Leech, Aspek Tutur meliputi penutur, lawan tutur, tujuan tutur, tuturan sebagai produk tindak verbal. Terkait dengan aspek tutur penutur dan lawan tutur ditegaskan bahwa lawan tutur atau petutur adalah orang yang menjadi sasaran tuturan dari penutur.

Menurut Hymes di dalam peristiwa tutur ada yang menandai keberadaan peristiwa itu. Setting atau tempat adalah suasana peristiwa tutur, Participants adalah penutur, petutur dan pihak lain, ends atau tujuan yaitu tujuan tuturan tersebut dituturkan, acts yaitu tindakan yang dilakukan oleh penutur di dalam peristiwa tutur, key yaitu nada suara atau ragam bahasa yang digunakan di dalam mengekspresikan tuturan dan cirri mengekspresikannya, Instrument merupakan alat yang digunakan pada saat penutur menuturkan tuturannya, Norms atau Norma adalah aturan yang harus dipatuhi oleh semua peserta tutur, dan yang terakhir adalah Genre adalah jenis kegiatan atau peristiwa itu sendiri.

\section{Klasifikasi Tindak Tutur}

Menurut Searl dalam Nadar ada 5 klasifikasi tindak tutur:

1. Assertive meliputi ungkapan suggest menyarankan, swear bersumpah, hypotheses membuat hipotesa.

2. Commisive meliputi ungkapan promise berjanji, threaten mengancam, offer menawarkan

3. Expressive meliputi ungkapan thank berterimakasih, congratulate mengucapkan selamat, welcome menyambut, complaint mengeluh.

4. Directive meliputi ungkapan command memerintah, request meminta, invite meminta

5. Declarative meliputi ungkapan declare menyatakan, dare menamakan, baptism membaptis, marrying menikahkan

Austin merumuskan tiga peristiwa tindakan yang berlangsung sekaligus yaitu: yaitu tindak tutur lokusi, ilokusi, dan perlokusi.

1. Tindak Lokusi, adalah tindak tutur untuk menyatakan sesuatu atau informasi The Acts of Saying Something. tuturan ini dituturkan oleh penutur semata-mata untuk memberikan informasi tanpa ada maksud apapun.

Contoh: bagus sekali nilai kamu.

2. Tindak Ilokusi, adalah tindak tutur yang berfungsi untuk menyatakan sesuatu dan digunakan untuk melakukan suatu tindakan. jika tindakan ini dilakukan maka menjadi tindak ilokusi The Acts of Doing Soemthing

Contoh: Bagus sekali nilai kamu

Jika tuturan ini dituturkan oleh teman, orang tua, guru kepada seseorang yang memang mendapat nilai A, maka tuturan ini sebagai pujian. Namun jika tuturan ini dituturkan pada seseorang yang mendapatkan nilai jelek, maka tuturan ini memiliki daya ilokusi sebagai sindiran.

3. Tindak perlokusi

tuturan yang memiliki daya atau efek bagi yang mendengarnya The Acts of Effecting Someone

Contoh: Bagus sekali nilaimu

jika tuturan ini dituturkan pada sesorang yang mmemiliki nilai bagus, maka efek yang akan ditimbulkan adalah orang tersebut akan senang dan bertutur terimakasih. Namun sebaliknya jika tuturan tersebut dituturkan pada seseorang yang memiliki nilai jelek maka efek yang ditimbulkan orang tersebut akan bersedih atau bahkan malu.

Dalam keseharian, ada kalanya penutur dalam mengungkapkan sesuatu secara langsung atau Tindak Tutur Langsung (TTL), Namun tidak jarang juga penutur lebih memilih mengungkapkan sesuatu dengan Tindak Tutur Tidak Langsung (TTTL). Tindak tutur tidak langsung adalah tindak tutur yang 
dilaksanakan dengan menggunakan bentuk tindak tutur yang lain Searl. Misalnya, ujaran "tutup pintu itu" dan "dapatkah anda menutup pintu itu?" kedua tuturan tersebut sama-sama memiliki maksud menyuruh seseorang menutup pintu. namun pada tuturan pertama penutur menggunakan tindak tutur langsung yaitu penutur langsung menyebutkan maksud tuturannya yaitu menyutur petutur membuka pintu. Sedangkan pada tuturan kedua, meskipun penutur memiliki maksud yang sama yaitu menginginkan agar petutur membuka pintu namun penututr mengemas tuturannya dalam sebuah pertanyaan. Tindak tutur ini merupakan tindak tutur tidak langsung yang jika dipilih, maka penutur benar-benar ingin menjaga muka dari lawan tuturnya. Jika ditinjau dari prinsip kerjasama beserta ke 4 bidalnya, maka tuturan kedua telah terjadi pelanggaran maksim quantity, yaitu penutur tidak informative menuturkan tuturannya. dengan adanya pelanggaran tersebut maka munculah implikatur.

\section{Implikatur}

Grice berpendapat bahwa agar percakapan dapat berjalan secara efisien, tidak membuang-buang waktu dan tenaga maka penutur harus mematuhi Prinsip Kerja Sama (PKS), yang dikenal dengan 4 bidal:

1. Bidal kuantitas, buatlah percakapan seinformatif mungkin sesuai yang diperlukan dan jangan melebih-lebihkan informasi yang diperlukan.

2. Bidal kualitas, jangan katakana apa yang menurut anda tidak benar dan jangan katakana sesuatu yang tidak ada bukti.

3. Bidal relasi, berikan ujaran yang relevan atau nyambung

4. Bidal cara, hindari ambiguitas, ungkapkan secara singkat, dan runtut.

Jenis-Jenis implikatur percakapan

Grice membedakan dua macam implikatur atau makna tersirat itu, Keduanya adalah implikatur konvensional dan implikatur non-konvensional atau implikatur percakapan.

Contoh:

1. Implikatur konvensional "Bahkan Bapak Dekan menghadiri ulang tahun saya”

Implikatur konvensional ujaran tersebut adalah bahwa bapak dekan biasanya tidak menghadiri ulang tahun saya.

2. Implikatur non-konvensional atau implikatur percakapan

A : Maukah anda menghadiri acara selamatan ulang tahun saya?

B : Saya kebetulan ke Amerika selama sebulan dan berangkat besok

Yang tersirat dari jawaban tersebut jawaban tidak. Namun jawaban ini tidak diberikan secara terus terang. Jika seseorang pergi ke luar negeri, ia tidak berada di Jakarta maka ia tidak dapat menghadiri selamatan yang dimaksudkan.

Dalam keseharian, ternyata tidak semua tuturan atau jawaban dari sebuah pertanyaan diujarkan dengan mematuhi PKS, Hal ini dikarenakan perlu menjaga hubungan sosial. Ketidakpatuhan kita kepada PKS Grice karena perlu menjaga muka. Dengan adanya pelanggaran bidal maka penutur mengemas tuturanya dalam tuturan tidak langsung atau tersirat, dalam pragmatik dikenal dengan istilah implikatur. Penggunaan implikatur atau penuturan tuturan secara tidak langsung memiliki motivasi agar dapat mengurangi dampak daya ujarannya. Hal ini tejadi bila ujaran berpotensi mengancam muka penutur maupun petutur. Tindak tutur yang mengancam muka disebut Face-threatening act (FTA), untuk mengurangi keterancaman muka maka penutur dan petutur akan melakukan tindak perlindungan muka face-saving act.

Dengan demikian untuk menyelamatkan muka penutur dan petutur atau meminimalkan FTA, maka setiap ujaran harus sangat diperhatikan isi dan juga cara menyampaikannya. Banyak penutur memilih untuk menuturkan tuturannya dengan cara tidak langsung atau samar, namun tidak jarang juga penutur langsung mengutarakan maksud tuturannya. Menurut Brown dan Levinson pada saat bertutur penutur harus juga memperhatikan kesantunan bertutur. Kesantunan untuk menjaga muka positif disebut kesantunan positif, sedangkan untuk menjaga negatiif disebut kesantunan negative.

1. Positive face/Muka positif: mengacu pada keinginan seseorang agar apa yang diasosiasikan dengan dirinya dinilai baikoleh orang lain.

2. Negative face/Muka negat mengacu ke keinginan seseorang agar tindakannya tidak diganggu oleh orang lain.

3. Positive politeness/kesantunan positif: Kesantunan yang digunakan untuk menjaga muka positif

4. Negative politeness/ kesantunan negatif: a face saving act which is oriented to the person's negative face. Kesantunan yang digunakan untuk menjaga muka negatif.

Berikut 5 strategi bertutur menurut Brown dan Levinson:

1. Bertutur terus terang tanpa basa basi (Bald record);

contoh: ganti bajumu

2. Bertutur terus terang dengan basa-basi berupa kesantunan positif (on record with positive politeness)

contoh: maukah kamu mengganti bajumu sebelum pergi? 
3. Bertutur terus terang dengan basa-basi berupa kesantunan negatif (on record with negative politeness)

contoh: tidak ada maksud menyinggung, tapi sepertinya kamu perlu mengganti bajumu

4. Bertutur secara samar (off record); contoh: ini pesta pernikahan lho.

5. "bertutur di dalam hati” penutur memilih diam (don't do the FTA).

\section{Teori relevansi}

Sperber dan Wilson mencoba mengevaluasi 3 bidal atau maksim dari Grice. Yang telah melanggar bidal kualitatif, kuantitatif, dan cara tetapi tetap berhasil karena adanya relevansi.

Teori relevansi dikenal juga dengan prinsip relevansi, prinsip ini berisi jaminan penutur Sperber dan Wilson, sehingga dapat disimpulkan bahwa:

1. Setiap ujaran mengandung jaminan relevansi penutur yang bonafide menjamin itu.

2. Tugas petutur memahami ujaran penutur dengan mencari relevansinya, untuk itu petutur memperhitungkan konteks (karena kemampuan kognitif setiap orang berbeda)

3. Dalam sebuah percakapan dengan adanya ujaran dalam sebuah situasi munculah sebuah meaning in interaction.

\section{HASIL DAN PEMBAHASAN}

Disini penulis akan membahas bagaimana strategi bertutur yang dipilih oleh para pemain sitkom Tukang Ojek Pengkolan pada saat menuturkan tuturan dengan maksud memerintah. Data tersebut diperoleh dalam tiap dialog dari para pemain sitkom ini lalu dikaitkan dengan teori tindak tutur dari Searl dan Brown and Levinson.

Data strategi bertutur pada tuturan memerintah dala sitkom Tukang Ojek Pengkolan

\begin{tabular}{|l|l|l|l|l|l|}
\hline data & \multicolumn{5}{|c|}{$\begin{array}{l}\text { Strategi bertutur } \\
\text { (Brown and Levinson) }\end{array}$} \\
\hline $\begin{array}{l}\text { TT } \\
\text { meme } \\
\text { rintah }\end{array}$ & $\begin{array}{l}\text { Bald } \\
\text { record } \\
\text { Data 1 }\end{array}$ & $\begin{array}{l}\text { On record } \\
+ \\
\text { politeness }\end{array}$ & $\begin{array}{l}\text { On record } \\
- \\
\text { politeness }\end{array}$ & $\begin{array}{l}\text { Off } \\
\text { record }\end{array}$ & $\begin{array}{l}\text { Don't } \\
\text { do } \\
\text { FTA }\end{array}$ \\
\hline Data 2 & $\sqrt{ }$ & & & $\sqrt{ }$ & \\
\hline Data 3 & & & & $\sqrt{ }$ & \\
\hline Data 4 & & & & $\sqrt{ }$ & \\
\hline Data 5 & $\sqrt{ }$ & & & & \\
\hline Data 6 & $\sqrt{ }$ & & & & \\
\hline
\end{tabular}

Data 1 (jalanan depan rumah ojak)

Di halaman, ojak menyela motor yang tak mau hidup.

Emak : Lakilu kagak ngojek?

Tati : Itu udah mau jalan
Emak : Kalau siang mulu jalannya, kapan dapat duitnya, keburu dipatok ayam!

Tati : Emang ayam mana yang suka matok duit, mak?

Emak : Itu perumpamaan tati!

Emak tampak kesal, tati bingung sementara Ojak masih sibuk menyela motor.

Dalam percakapan antara Emak dan Tati, terjadi saat Emak berkunjung ke kontrakan tati. Hari sudah beranjak siang, namun Ojak masih terlihat di rumah dan masih sibuk menyela motornya. Maka dengan nada kesal Emak berujar "lakilu kagak ngojek?” dengan ujaran ini emak mengira kalau hari itu Ojak tidak kerja, karena saat Emak datang ojak masih di rumah yang sibuk dengan motornya. Implikatur yang dihasilkan adalah Emak mengira Ojak tidak kerja, kondisi tersebut diperoleh berdasarkan pengetahuan jika orang berangkat kerja umumnya dipagi hari, jadi jika emak datang ke kontrakan pada siang hari seharusnya Emak tidak akan bertemu Ojak. Ujaran tersebut masih relevan dengan situasi saat percakapan berlangsung yaitu siang hari dan Ojak terlihat masih di depan rumah yang sedang sibuk dengan motornya.

Implikatur juga muncul pada ujaran Emak yang kedua, "kalo siang mulu jalannya, kapan dapat duitnya, keburu kepatok ayam”. Kondisi tersebut diperoleh berdasarkan pengetahuan bahwa pada umumnya berangkat kerja di pagi hari, selain itu ada sebuah kepercayaan di masyarakat yang cukup diyakini oleh sebagian orang jika bangun atau berangkat kerja di siang hari maka rizki akan menjauh darinya dikenal dengan istilah dipatok ayam. Pada ujaran kedua ini mengandung maksud memerintah yang dilakukan oleh emak kepada Ojak melalui tati yaitu untuk lebih giat bekerja, mendapatkan uang yang banyak sehingga tati yang merupakan anak Emak dan istri Ojak tidak akan kekurangan materi. Ujaran tersebut diungkapkan secara deklaratif.

Pada saat tuturan tersebut dituturkan oleh emak "kalo siang mulu jalannya, kapan dapat duitnya, keburu kepatok ayam”. Emak tidak secara langsung menuturkan maksudnya, dia memilih menggunakan perumpamaan "keburu kepatok ayam" dalam masyarakat dikenal istilah ini, jika bermalas-malasan untuk berangkat kerja dipagi hari maka kalah dengan ayam, tidak akan dapat rizki yang banyak. Strategi bertutur yang digunakan oleh Emak adalah bertutur secara samar atau Off record. Strategi ini digunakan oleh penutur (Emak) untuk meminimalkan keterancaman muka petutur yaitu (Ojak) jika dituturkan secara langsung maka kemungkinan Ojak akan merasa tersinggung. Selain itu bertutur secara samar dipilih oleh Emak karena beberapa pertimbangan, salah satunya adalah didasarkan pada tingkat kedekatan Emak dan Ojak. Hal ini tercermin 
dalam sebuah kenyataan yaitu antara Emak dan menantu, meskipun Emak selalu sinis jika dia berbicara pada Ojak, namun dalam hal ini Emak masih berusaha menyampaikan maksudnya agar Ojak lebih giat bekerja agar dapat uang banyak untuk dapat membahagiakan tati yang merupakan Emak satu-satunya. Pada situasi ini Ojak cukup merasa rishi dan malu, namun semua itu masih dapat diminimalkan berkat strategi bertutur yang digunakan oleh Emak yaitu tuturan samara tau off record. Hal ini terlihat dari ekspresi dan jawaban Ojak dengan senyum tipisnya dan jawabannya "iya mak" sambil menghela nafas.

Data 2 (Emak dan Tati masih berdiri di jalan. Sesekali Emak melihat ke Ojak yang masih memanaskan motor di teras.

Emak : Elu jangan keenakan tidur di kontrakan terus. Elu dorong laki lu biar jangan males nyari duit! Biar punya rumah sendiri!

Tati : Entar kalo di dorong bang Ojak jatuh, mak!

Saat Emak masih melihat Ojak sibuk dengan motor bututnya yang sepertinya susah untuk dinyalakan, Emak makin merasa kesal, itu berarti Ojak akan semakin siang berangkat ngojeknya dan bisa saja berakibat makin sedikit pedapatannya. Dengan nada sedikit sewot, emak menasehati tati sebagai istri Ojak dengan bertutur "Elu dorong laki lu biar jangan males nyari duit! “ sebagai orang tua tati, Emak merasa prihatin dengan kondisi keuangan rumah tangga tati dan Ojak. Implikatur yang dihasilkan adalah tati sebagai istri Ojak sudah seharusnya mendukung suami, selain itu juga wajib bagi Tati untuk selalu mengingatkan Ojak giat dalam berkerja, agar keuangan rumah tangganya semakin membaik.

Tuturan Emak pada Tati yaitu "Elu dorong laki lu biar jangan males nyari duit!“ memiliki maksud memerintah agar tati selalu mendorong atau mengingatkan ojak untuk lebih giat bekerja dengan cara berangkat ngojek lebih pagi. Tuturan ini dituturkan oleh Emak dengan pengetahuan bahwa jika semakin pagi memulai aktifitas untuk bekerja, badan masih segar, pikiran masih fokus dengan demikian maka makin banyak pula rizki yang akan diperoleh.

Emak dalam memberikan tuturannya "Elu dorong laki lu biar jangan males nyari duit!“ sangat jelas maksud dari tuturan Emak pada Tati yaitu memerintah Tati untuk mengingatkan Ojak agar lebih giat bekerja yaitu ngojek. Strategi bertutur yang dipilih emak yaitu bald record strategi ini digunakan dengan cara penutur langsung menyampaikan maksud tuturannya yaitu memerintah pada petutur. Emak memerintah tati agar terus memberi motivasi pada suaminya untuk terus lebih giat bekerja. Dalam hal ini Penutur tidak terlalu memperhatikan keterancaman muka si petutur, hal ini karena adanya hubungan kedekatan antara emak dan tati yaitu sebagai ibu dan anak. Pada dasarnya emak sudah memahami bagaimana cara menghadapi Tati, serta bagaimana cara mengarahkan tati agar dia bisa lebih bersikap pada Ojak terlebih dalam memberi semangat pada Ojak untuk giat bekerja.

Data 3 (Emak tampak makin bête, gelisah karena mau ngaji, Babe masih melirik Emak).

\begin{tabular}{|c|c|}
\hline ma & $\begin{array}{l}\text { Maaf ni be, abis lohor saya mi } \\
\text { berangkat ngaji }\end{array}$ \\
\hline $\mathrm{abc}$ & $\begin{array}{l}\text { : Lah, napa lo kagak ngomong da } \\
\text { tadi? }\end{array}$ \\
\hline $\mathrm{m}$ & $\begin{array}{l}\text { : Saya tadi mau bilang, tapi babe } \\
\text { ngomong terus }\end{array}$ \\
\hline$a b$ & $\begin{array}{l}\text { : Ngom,ong terus begimane, kan ta } \\
\text { kita sempet diem-dieman lama }\end{array}$ \\
\hline $\mathrm{ma}$ & : Emang, tapi pa \\
\hline
\end{tabular}

Saat babe bertamu di rumah emak, emak terlihat semakin bête dan gelisah, dia tidak tau bagaimana caranya agar babe segera pulang. Emak kurang merasa nyaman saat babe berkunjung ke rumahnya. Babe memiliki perasaan khusus pada emak, namun tampaknya tidak demikian dengan emak. Hubungan kedekatan keduanya cukup dekat sebagai tetangga, namun perbedaan usia diantara keduanya membuat emak merasa sungkan saat ingin memerintah babe pulang. Akhirnya emak bertutur "maaf ni be, abis lohor saya mau berangkat ngaji”. implikasi dari tuturan ini adalah, hari sudah menjelang lohor, maka emak harus segera bersiap untuk berangkat mengaji. Pengajian ini khusus untuk kaum perempuan, jadi tidak ada alasan lagi bagi babe untuk ikut. Selain itu perbedaan usia mereka berdua membuat emak lebih hormat dan perlu berhati-hati saat bertutur pada babe untuk menyampaikan maksudnya. Hal ini khususnya terlihat saat emak bermaksud menyuruh babe untuk pulang.

Emak bertutur "maaf ni be, abis lohor saya mau berangkat ngaji” memiliki maksud agar babe sesegera mungkin pergi dari rumah emak. Tuturan ini dituturkan oleh emak dengan pengetahuan bahwa seseorang yang akan berangkat mengaji memerlukan waktu untuk bersiap-siap dan menunaikan sholat lohor terlebih dulu. Dengan tuturan tersebut, tersirat harapan emak bahwa babe akan memahami maksudnya dan akan segera berpamitan.

Dalam tuturannya "maaf ni be, abis lohor saya mau berangkat ngaji” yang didahului dengan kata "maaf” sangat jelas bahwa emak menaruh hormat pada babe, maksud utama dari tuturan tersebut adalah emak memerintah babe agar segera pergi dari 
rumahnya, namun dalam tuturan emak sama sekali tidak ada tuturan pergi atau pulang yang ditujukan pada babe. Berdasarkan hal tersebut jelas bahwa emak menggunakan strategi bertutur secara samar atau off record. Strategi ini digunakan oleh emak untuk meminimalkan keterancaman muka petutur yaitu babe. Emak masih menaruh hormat pada babe, meskipun sering bête jika babe berkunjung ke rumah. Oleh karena itu emak berusaha tetap menjaga perasaan babe agar jangan sampai tersinggung. off record atau tuturan samar merupakan pilihan strategi bertutur yang tepat, karena dengan strategi ini keterancaman muka yang kemungkinan dapat dialami oleh babe terhindarkan. dengan sebuah pernyataan "maaf ni be, abis lohor saya mau berangkat ngaji”

Data 4 (tisna berhenti ketika melihat ada motor parkir diteras dengan tulisan "DIJUAL" tisna turun mendekati ujang yang sedang mengelap motor).

$$
\begin{array}{ll}
\text { Tisna } & \text { : Maaf, harganya berapa? } \\
\text { Ujang } & \text { : } 5 \text { juta } \\
\text { Tisna } & : \text { Mahal, ya? } \\
\text { Ujang } & \text { : Kalau mau murah, beli sepeda aja. } \\
& \text { (ujang lanjut mengelap motornya). }
\end{array}
$$

Tisna ingin mengganti motornya, selain motornya sudah terlihat kusam juga sering mogok yang akhirnya banyak penumpang kecewa. Tisna berkeliling kampung dengan motornya mencari penjual motor seken. Beberapa menit berselang tisna melihat ada motor yang sedang diparkir dan dilap bertuliskan "DIJUAL", dia berhenti dan bertanya tentang harga motor tersebut, "5 juta" jawab si penjual. Tisna jawab “mahal ya?” dengan wajah sedih, dengan suara datar penjual menjawab "kalau mau murah, beli sepeda aja”. Jawaban Ujang berimplikasi bahwa ujang kesal atas respon yang diberikan oleh tisna saat tisna menanyakan tentang harga motor yang dia jual, hal ini diperoleh berdasarkan pengetahuan ujang tentang harga motor baru diatas kisaran 12 juta keatas, sedangkan untuk harga seken paling tidak diatas kisaran 7-8 juta, sementara dia akan menjual motor sekennya dengan harga 5 juta sudah termasuk murah. Namun diluar dugaan ternyata tisna masih menganggap 5 juta masih mahal. Dengan demikian tuturan ujang "kalau mau murah beli sepeda aja” tuturan ini berimplikasi bahwa jika ingin murah tisna lebih baik membeli sepeda yang sudah pasti harganya jauh lebih murah atau dibawah 5 juta.

Tuturan "kalau mau murah beli sepeda aja" yang dituturkan oleh ujang memiliki maksud memerintah pada Tisna agar pilih membeli sepeda jika dia ingin mendapatkan harga yang murah. Hal ini diperoleh dari jawaban tisna "mahal ya”, dengan harga 5 juta untuk mendapatkan sebuah motor seken dengan kondisi baik termasuk harga yang cukup murah. Tuturan ujang juga dapat memiliki maksud lain yaitu memerintah agar Tisna segera pergi dari tempat ujang, karena tidak memungkinkan bagi Tisna untuk menawar lebih rendah dari 5 juta, dan yang pasti di rumah ujang tidak jual sepeda.

Tisna dan ujang merupakan dua orang yang sebelumnya belum saling kenal. Mereka berdua terlibat pembicaraan sebagai seorang penjual dan pembeli motor. Diantara keduanya harus ada sikap saling menghargai. pada saat tisna mengetahui harga sepeda motor, dia langsung menjawab "mahal ya" ujang nampak kaget dan kesel, maka Ujang bertutur “kalau mau murah beli sepeda aja” tuturan ini tidak benar-benar menyuruh tisna untuk beli sepeda, melainkan memerintah agar tisna segera pergi dari tempat itu, karena mungkin saja ujang tidak akan membuka tawar menawar harga. Hal ini diperkuat dengan situasi bahwa memang ditempat ujang tidak ada sepeda, dan jika benar tisna membeli sepeda sudah pasti dia harus cari di tempat lain (dia harus pergi). Strategi bertutur secara samar atau off record yang dipilih oleh Ujang. Ujang tidak ingin mengancam muka Tisna dengan merespon lebih jauh tuturan Tisna, meskipun ujang kesal, tapi dia masih berusaha untuk menyelamatkan muka lawan tuturnya, karena bagaimanapun juga Tisna adalah calon pembeli yang tetap harus dihornati meski dia tidak jadi membeli motor tersebut.

Data 5 (ujang melanjutkan mengelap motornya. Tisna pergi dengan wajah kesal. tak lama kemudian Ojak muncul dari arah pengkalan dan menghampiri ujang)
Ojak : Tadi temen saya ngapain?
Ujang : Nanyain harga motor ini.
Ojak : Trus lo jawabnya berapa?
Ujang : Tanya aja sama temen abang itu.

Niat yang sama juga dimiliki oleh ojak untuk mengganti motornya. Dia tiba ke rumah ujang setelah beberapa menit tisna pergi meninggalkan tempat itu. Ojak bertanya pada ujang, tentang apa apa yang abru saja dilakukan oleh Tisna di depan rumahnya. Ujangpun menjawab tentang maksud Tisna tadi. Ojak melanjutkan pertanyaanya lagi tentang jawaban ujang mengenai harga motor yang ditanyakan oleh Tisna. Ujang menjawab dengan bertutur "Tanya aja sama temen abang”. Maksud Ujang bertutur demikian adalah dengan pengetahuan bahwa sebelumnya Ojak bertanya "tadi temen saya ngapain?” berarti antara Ojak dan Tisna ada hubungan kedekatan yaitu sebagai teman dan sudah pasti mereka berdua akan sangat mudah berbagi informasi mengenai informasi harga yang sudah diketahui oleh Tisna sebelumnya. Tuturan Ujang juga memiliki implikasi bahwa dia masih merasa kesal atas sikap Tisna sebelumnya, selain itu Ujang 
enggan untuk mengulang jawaban yang sama tentang informasi harga motor seken yang akan dia jual. Hal ini disebabkan oleh anggapan Ujang kepada Ojak yang pasti akan melakukan hal yang samam yaitu sama-sama tidak membeli motor seken tersebut. Oleh karena itu Ujang memerintah Ojak untuk bertanya pada temannya yaitu Tisna.

Tuturan Ujang “Tanya aja sama temen abang” mengacu langsung pada maksudnya yaitu memerintah agar Ojak menanyakan tentang harga motornya pada Tisna. Hubungan kedekatan antara Ojak dan Ujang hampir tidak ada, karena mereka baru pertama bertemu saat itu. Ujang memilih menuturkan “Tanya aja sama temen abang” karena menurutnya tidak ada alasan bagi dia untuk menjaga muka petutur yaitu Ojak. Ojak bukan pembeli seperti Tisna. Ojak hanya mencoba mencari informasi tentang apa yang baru saja Tisna lakukan di rumah Ujang. Strategi bertutur yang dilakukan oleh Ujang adalah Bald record, strategi ini dilakukan dengan cara penutur langsung menuturkan maksud tuturannya tanpa mempertimbangkan keterancaman muka si petutur dalam hal ini Ojak. Hal ini terlihat dari tuturan Ujang dan ternyata benar Ojak sama sekali tidak tercermin dari raut wajahnya jika dia tersinggung atas tuturan Ujang. dia langsung berlalu dari hadapan Ujanng dengan senyumnya.

Data 6 (Babe dan Emak sedang ngobrol sambil ngopi di teras rumah emak)

Babe : Gua kalo ngobrol begini jadi inget masa lalu.

Emak : Saya sih engga inget be.

(babe kecewa, Tapi semangat lagi)

Babe : Nah kalo cerita ini pasti lo inget.

Emak : Kayaknya saya juga nggak inget.

Babe : Lah, pan gua belum cerita.

Emak : Ya udah babe cerita deh.

Percakapan antara Emak dan Babe berawal dari kehadiran Babe ke rumah Emak yang ingin dibuatkan kopi oleh Emak. Ceritapun berlanjut dengan Babe memancing pembicaraan dengan Emak dengan tuturan "gua kalau ngobrol begini jadi inget masa lalu” namun jawaban Emak tidak sesuai dengan harapan Babe melalui jawaban "saya sih nggak inget beh” menunjukan bahwa Emak tidak terlalu nyaman dengan kehadiran babe. Hal ini juga didukung dengan raut muka Emak saat menuturkan tuturan tersebut. Tidak sampai disitu Babe tetap berusaha memancing agar tercipta pembicaraan dengan kembali berujar "nah kalo cerita yang ini lo pasti inget” langsung direspon oleh Emak "kayaknya saya juga nggak inget” kembali Emak menunjukan ketidaknyamananya. Beberapa respon Emak yang dituturkan sangat jelas menunjukan bahwa Emak merasa tidak nyaman dan ingin segera mengakhiri perbincangan dengan Babe. Namun usaha tersebut sia-sia, Babe sama sekali tidak tanggap atas apa yang dituturkan oleh Emak.

Akhirnya Emak kembali merespon dengan jawaban “ya udah, Babe cerita deh". Tuturan ini merupakan respon dari atas semua tuturan Babe, dengan didukung mimic muka Emak yang menunjukan bête, ketidaknyamanan atas situasi saat itu. tuturan emak bermaksud menyuruh babe untuk menceritakan apa yang sebenarnya ingin Babe sampaikan. selain tutran Emak memiliki maksud memerintah, terdapat juga makna lain yang tersirat yaitu Emak tidak ingin basa-basi lagi agar obrolan antara dia dan Babe segera berakhir dan babe segera pulang. Hal ini diketahui dari tuturan "ya udah, babe cerita deh" dibarengi dengan raut muka yang tidak begitu ceria. Emak menggunakan strategi bertutur jenis bald record karena emak langsung bertutur pada maksud sesungguhnya yaitu memerintah agar babe segera bercerita. Strategi ini dipilih oleh emak karena tidak ada pilihan lain bagi Emak untuk menunjukan rasa tidak nyaman jika Babe berlama-lama bertamu, dengan tuturan berikut "saya sih nggak inget beh" dan "kayaknya saya juga nggak inget”. Akhirnya emak bertutur “ya udah, babe cerita deh". memberi kesempatan babe untuk bercerita tentang pengalamnnya dengan emak.

\section{KESIMPULAN}

Pada sitkom tukang Ojek Pengkolan ini terdapat banyak sekali jenis tindak tutur yang dituturkan oleh para pemainnya. Namun sesuai dengan batasan masalah yang sudah penulis paparkan sebelumnya, dalam hal ini penulis hanya fokus dalam pencarian data tentang tuturan memerintah. Dalam bertutur seorang penutur tidak hanya sekedar menyampaikan sebuah maksud, melainkan harus memperhatikan hubungan kedekatan keduanya, serta tingkat keterancaman muka antara penutur dan petutur. Sebuah tuturan masing-masing memiliki maksud yang berbeda, dalam tulisan ini penulis telah melakukan pengamatan tentang tuturan memerintah dalam sitkom TOP dan sekaligus melihat bagaimana strategi bertutur yang digunakan oleh masingmasing karakter saat menuturkan tuturan memerintah.

Penulis memperoleh simpulan bahwa strategi bertutur yang digunakan oleh para pemain sitkom TOP pada saat menuturkan tuturan memerintah adalah menuturkan secara samar (off record) dan jelas (bald record). Berdasarkan teori brown levinson, pada saat penutur menggunakan strategi off record berarti penutur sangat mempertimbang-kan dan menjaga kemungkinan keterancaman muka dari lawan tutur dan juga penuturnya. Hal ini dipengaruhi oleh hubungan kedekatan seperti anak dan orang tua, kakak adek, serta hubungan dengan orang yang lebih tua, serta perbedaan tingkat status social. Sedangkan bald record dipilih oleh beberapa karakter dalam sitkom ini sebagai strategi bertutur yang sama sekali 
tidak mempertimbangkan keterancaman muka dari lawan tutur.

\section{REFERENSI}

Austin, J.L.1992. How to Do Things With Words. Harvard University Press: Cambridge. Mass

Brown, Penelope and Stephen C. Levinson. Politeness: some universals in Language Usage. New York: Cambridge University Press, 1987.

Grice, H.P.1975. “Logic and Conversation”. Syntax and Semantics, Speech Act, 3 New York: Academic Press.

Hymes, Dell. 1972. Language In Culture and Society. New York: Harper and Row

Leech. N Geoffrey. 1983. Principle of Prgamatics. Cambridge: Cambridge University Press.

Levinson, Stephen C. 1991. pragmatics. Cambridge: Cambridge University Press.
Nadar, F.X. 2009. Pragmatik \& Penelitian Pragmatik. Yogyakarta; Graha ilmu.

Searl, john, Ferenc kiefer dan Manfred Bierwisch (Eds). 1980. Speech Act Theory and Pragmatics. Dondrecht, Holland: D.Reidel Publishing Company.

Wardaugh, Ronald. 1986. An Introduction to Sociolinguistics. Oxford: Basil Blacwell ltd.

Yule, George, 1996. Pragmatics New York:Oxford UP.

\section{PROFIL PENULIS}

Prapti Wigati Purwaningrum, SS, M.Hum was born in Kebumen, 3 May 1984. She graduated from Sekolah Tinggi Bahasa Asing LIA Jakarta majoring linguistic and post graduate program state university of Jakarta Majoring applied Linguistic. She has been teaching for almost 9 years. Now she is a lecturer at ABA BSI Jakarta. 